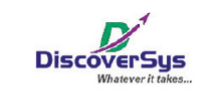

Published by DiscoverSys

\title{
Correlation between physical characteristics of the indoor environment toward the concentration of fungi in the inpatient rooms of dr. Soebandi Regional Hospital Jember, East Java
}

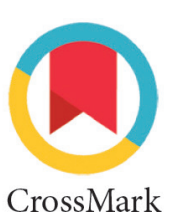

\author{
Salsabilla Maula Zalfa El Hamzah, ${ }^{1}$ Astuti Setyawardani, ${ }^{1}$ \\ I Nyoman Semita, ${ }^{2}$ Dini Agustina ${ }^{3 *}$
}

\begin{abstract}
Background and purpose: Air quality is an important determinant of a healthy life. One indicator of air pollutants in the room is fungi, which in hospital setting may cause nosocomial infection. This research aims to find out a correlation between physical characteristics of the indoor environment toward the concentration of fungi in the inpatient rooms of $\mathrm{dr}$. Soebandi Regional Hospital Jember, East Java.

Methods: This research uses a cross-sectional method with a total of four inpatient rooms. We measured physical room characteristics including room temperature, humidity, light intensity, and room density. The concentration of fungi was measured by collecting air sample using passive air sampling method with a potato dextrose agar as the media to optimize the fungal growth. The data was

processed with Saphiro-Wilk and Pearson correlation analysis using SPSS 25.0.

Results: The ranges of room temperature and humidity were 29.6$32.2^{\circ} \mathrm{C}$ and $41-59 \%$, respectively; while the light intensity and room density were $10-30$ and $1.88-2.38$ person/10 $\mathrm{m}^{2}$. The bivariate analysis showed a correlation between two components of physical characteristic of the indoor environment, room temperature and room density, with the concentration of fungi.

Conclusion: There is a correlation between room temperature and room density with the concentration of fungi in the inpatient rooms of dr. Soebandi Regional Hospital Jember. The management of hospitals should take measures to improve the air quality within inpatient rooms.
\end{abstract}

Keywords: Fungi, nosocomial infections, physical characteristics, indoor environment

Cite this Article: Hamzah, S.M.Z.E., Setyawardani, A., Semita, I.N., Agustina, D. 2020. Correlation between physical characteristics of the indoor environment toward the concentration of fungi in the inpatient rooms of dr. Soebandi Regional Hospital Jember, East Java. Public Health and Preventive Medicine Archive 8(1): 77-83. D0l: 10.15562/phpma.v8i1.225

\section{INTRODUCTION}

Air quality is an important determinant of healthy life. ${ }^{1}$ Physical characteristic of the indoor environment depends on various gases and particles circulating in it, both abiotic agents/characteristics such as dust, temperature, humidity, light and room density as well as biotic agents such as bacteria, viruses and fungi. ${ }^{2}$ Poor physical characteristic of the indoor environment in hospitals can lead to increase likelihood of nosocomial infections. ${ }^{3}$ The nosocomial infection can occur in patients treated in the hospital room with a large capacity where patients with different diseases are hospitalized in the same room. ${ }^{4}$

One indicator of indoor air pollutants is fungi. ${ }^{4}$ Studies have shown that there is a countable percentage of infections associated with hospitalization due to fungi, such as Candida albicans and various species of Aspergillus and Penicillium. The presence of fungi in the air in a hospital room can be influenced by other factors such as physical characteristic of air quality and the density of the room. ${ }^{3-5}$ The physical characteristic of the indoor environment consists of several components such as temperature, humidity, lighting and room density. ${ }^{3,5}$

According to Indonesian Ministry of Health Regulation No.7 Year 2019, lighting in hospital rooms are needed to carry out activities effectively. A building can be considered healthy if it has sufficient light. Besides lighting, room temperature is also an important factor that influences the growth of microorganisms such as fungi. ${ }^{6}$ Budhyowati et al. (2016) found that room temperature influenced by several factors, including external factors such as sunlight, and internal factors such as the number of people, air ventilation and other lighting sources. Human body can release heat into the air through four ways, such as convection, conduction, radiation, and evaporation. ${ }^{7}$ Meanwhile, oxigen $\left(\mathrm{O}_{2}\right)$ levels in the room will decrease with the increasing 
number of occupants in the room. An increase of carbondioxide $\left(\mathrm{CO}_{2}\right)$ and water $\left(\mathrm{H}_{2} \mathrm{O}\right)$ follows the decreasing of $\mathrm{O}_{2}$, which will impact on an increase of humidity of the indoor air because the moisture content in the room increases. The condition of the room with the high dense level also related to the level of humidity, which is very influential to the rise in the concentration of fungi. ${ }^{8}$

Previous studies conducted in the inpatient room of dr. Soebandi Regional Hospital Jember found Aspergillus spp, Penicillium spp and Candida spp in the room and a significant correlation between the physical characteristic of air quality such as temperature and humidity with the concentration of air fungi. ${ }^{9}$

Based on these backgrounds, this study aims to determine the physical characteristics of the inpatient rooms including temperature, humidity, light intensity, room density, and the concentration and the type of fungi. We also explore the correlation between the physical characteristics of the indoor environment with the concentration of fungi in the inpatient room of dr. Soebandi Regional Hospital Jember. This research is expected to provide additional information regarding the correlation between physical characteristics of the indoor environment and the concentration of fungi which can be used as a consideration in the formulation of policies in improving air quality at $\mathrm{dr}$. Soebandi Regional Hospital Jember for the community.

\section{METHODS}

This study uses a cross-sectional approach. The population in this study was the inpatient rooms of dr. Soebandi Regional Hospital Jember with a total of 16 rooms. A purposive sampling technique was applied to obtain the sample of a total four inpatient rooms, with consideration to represent floor levels, and patients characteristics hosted within the room including children, male adult and female adult. Selected rooms do not have patients with fungal infection in order to avoid bias. Selected room were Anthurium (male adult ward), Aster (children ward), Adenium and Dahlia (female adult ward).

The air sampling was carried out using the passive air sampling method or also called diffusive air sampling, an air sampling technique conducted by placing an opened dense agar media inside the room for a certain period. For this study, we placed the potato dextrose agar (PDA) media in the middle of the room at a distance of one meter from the floor which was left open for 30 minutes. Then the media was placed in an incubator with a temperature of $36^{\circ} \mathrm{C}$ for six days to grow the fungi.

Measurements of temperature, humidity, light intensity, and room density were done by using thermohygrometer, light meter and counter that have been tested functionally and calliberated. Measurements and air sampling were carried out twice in each room during visiting and non-visiting hours.

Measurement was carried out under the Operational Standards for Taking and Measuring Hospital Room Air Quality Samples listed in the Indonesia Ministry of Health Decree No. 1335/ MENKES/SK/X/2002 where we need to avoid direct heat from the sun. ${ }^{10}$ Temperature measurement was done by firstly testing the function of the thermohygrometer. Temperature and humidty measurements were carried out twice in each room during visiting and non-visiting hours. ${ }^{10}$ For the light intensity measurement, light meter was used and the measurement was conducted from the furthest bed room the light source. The results of light intensity measurements in this study based on measurements done in the relevant inpatient room using a light meter.

Room density measurements were conducted using a counter which we measured since the medium was placed..$^{10}$ Room density measurements were carried out every 10 minutes since opening the agar media with a counter for more accurate results. The four results $(0,10,20$ and 30 minutes) are added up then divided by four to find the mean value.

Data analysis in this study include univariate and bivariate analysis. Univariate analysis was performed by describing the values of room temperature, room humidity, room light intensity, room density and the concentration of room fungi colonies. Bivariate analysis using the Pearson correlation was conducted to determine correlation between the physical characteristic of the indoor environment with the concentration of fungi. The Medical Faculty Research Ethics Commission of the University of Jember has approved this study with ethics grant number 1324/H25.1.11/KE/2019.

\section{RESULTS}

The final result for the room density in the area of the room shared by the number of mean number of occupants. Room temperature, humidity, light intensity and room density measurement results can be seen in detail in Table 1 .

The number of fungi colonies obtained from this study is based on direct calculations by researchers with the help of a manual colony counter tool. The concentration of fungi colonies was counted by three people whose results were then averaged with the final result using the $\mathrm{CFU} / \mathrm{m}^{3}$ unit. The number of fungi colonies can be seen in detail in Table 2 .

For the fungal identification, we found ten types 
Table 1. Room temperature, humidity, light intensity, and density of inpatient rooms

\begin{tabular}{|c|c|c|c|c|c|c|c|c|}
\hline \multirow[b]{2}{*}{ Room name } & \multicolumn{2}{|c|}{ Room temperature $\left({ }^{\circ} \mathrm{C}\right)$} & \multicolumn{2}{|c|}{ Room humidity (\%) } & \multicolumn{2}{|c|}{$\begin{array}{l}\text { Room light Intensity } \\
\text { (Iux) }\end{array}$} & \multicolumn{2}{|c|}{$\begin{array}{l}\text { Room density } \\
(\text { person/10 m²) }\end{array}$} \\
\hline & $\begin{array}{l}\text { Visiting } \\
\text { hours }\end{array}$ & $\begin{array}{l}\text { Non- } \\
\text { visiting } \\
\text { hours }\end{array}$ & $\begin{array}{l}\text { Visiting } \\
\text { hours }\end{array}$ & $\begin{array}{c}\text { Non- } \\
\text { visiting } \\
\text { hours }\end{array}$ & $\begin{array}{l}\text { Visiting } \\
\text { hours }\end{array}$ & $\begin{array}{c}\text { Non- } \\
\text { visiting } \\
\text { hours }\end{array}$ & $\begin{array}{l}\text { Visiting } \\
\text { hours }\end{array}$ & $\begin{array}{c}\text { Non-visiting } \\
\text { hours }\end{array}$ \\
\hline Adenium & 29.6 & 30.3 & 59 & 58 & 10 & 22 & 2.15 & 2.04 \\
\hline Anthurium & 30.7 & 31 & 53 & 55 & 30 & 16 & 2.95 & 2.38 \\
\hline Aster & 30.8 & 32.3 & 54 & 51 & 20 & 18 & 2.24 & 2.01 \\
\hline Dahlia & 30.1 & 29.6 & 41 & 56 & 14 & 16 & 1.95 & 1.88 \\
\hline
\end{tabular}

\section{Table 2 The concentration of fungal colonies}

\begin{tabular}{lcc}
\hline \multirow{2}{*}{ Room name } & \multicolumn{2}{c}{ Concentration of fungal colonies $\left(\mathbf{C F U} / \mathbf{m}^{\mathbf{3}}\right)$} \\
\cline { 2 - 3 } & Visiting hours & Non-visiting hours \\
\hline Adenium & 47.97 & 2.85 \\
Anthurium & 58.94 & 12.19 \\
Aster & 32.11 & 26.83 \\
Dahlia & 4.47 & 1.63 \\
\hline
\end{tabular}

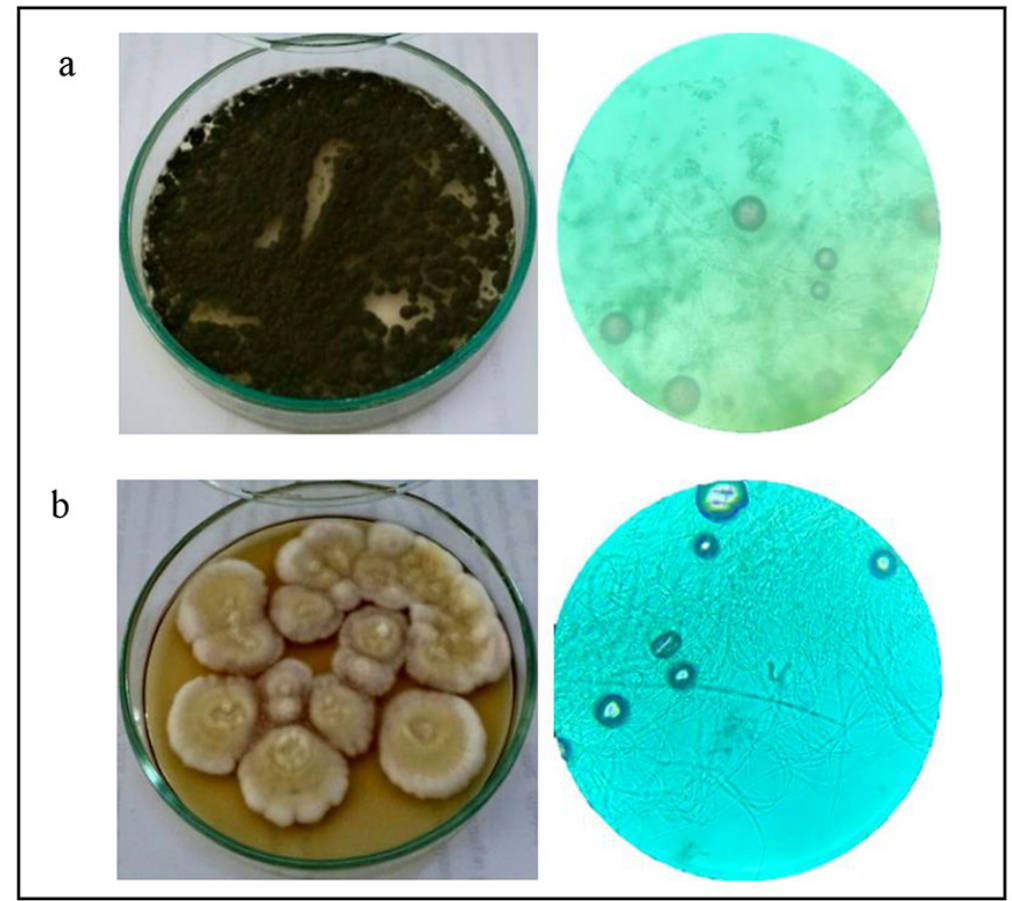

Figure 1. Fungi identification a) Exophiala xenobiotica; b) Blastomyces dermatitidis of fungus in the inpatient rooms of dr. Soebandi Regional Hospital Jember, which are Alternaria sp., Aspergillus niger, Blastomyces dermatitidis, Chrysosporium sp., Cladosporium cladosporioides, Exophiala xenobiotica, Neoscytalidium dimidiatum, Neurospora crassa, Penicillium sp., and Trichosporon $s p$. (Figure 1).

The results of the Pearson correlation test showed that there was a significant correlation between room temperature and the concentration of fungi at non-visiting hours with a correlation coefficient of $0.974(\mathrm{p}=0.026)$ which signifying a strong correlation. Moreover, there was a significant correlation between room density and the concentration of fungi with a correlation coefficient of 0.726 ( $\mathrm{p}=0.041)$ which also signifying a strong correlation between room density and fungal concentration. The results of Pearson correlation test on other variables did not show any significant correlation (Table 3).

\section{DISCUSSION}

The results of room temperature measurements in this study show that the inpatient room temperature of dr. Soebandi Regional Hospital Jember does not comply with existing regulations. According to the Republic of Indonesia Health Ministry Regulation No.7 Year 2019, the ideal temperature for treatment in hospitals is $22-23^{\circ} \mathrm{C}^{6}$, while the temperature of inpatient rooms of $\mathrm{dr}$. Soebandi Regional Hospital Jember was 29.6$32,2^{\circ} \mathrm{C}$. Previous study conducted in 2018 at $\mathrm{dr}$. Soebandi Regional Hospital Jember by Nafilahsari

Table 3. Correlation between room physical characteristics and fungi concentration

\begin{tabular}{|c|c|c|c|c|c|c|}
\hline \multirow[b]{2}{*}{ Indicators } & \multicolumn{2}{|c|}{ Room temperature } & \multirow[b]{2}{*}{ Room humidty } & \multicolumn{2}{|c|}{ Room light intensity } & \multirow[b]{2}{*}{ Room density } \\
\hline & $\begin{array}{c}\text { Visiting } \\
\text { hours }\end{array}$ & $\begin{array}{l}\text { Non-visiting } \\
\text { hours }\end{array}$ & & Visiting hours & $\begin{array}{l}\text { Non-visiting } \\
\text { hours }\end{array}$ & \\
\hline Correlation coeficient & 0.130 & 0.974 & 0.216 & 0.517 & -0.164 & 0.726 \\
\hline Sample size & 4 & 4 & 8 & 4 & 4 & 8 \\
\hline p-value & 0.860 & 0.026 & 0.607 & 0.483 & 0.836 & 0.041 \\
\hline
\end{tabular}


(2018) found the temperature of the inpatient room of was between $27.1-28^{\circ} \mathrm{C} .{ }^{9}$ We found no significant correlation between temperature and concentration of fungi during visiting hours. This finding differs from study conducted by Setyawardani (2019) that found a significant correlation between the number of people in the room and the concentration of fungi. ${ }^{11}$ Similarly, Jung et al. (2014) proposed that the more human activity in the room, the more microorganisms living in the air. ${ }^{12}$

The humidity standard in the inpatient room is around $40-60 \%$ based on the Indonesian Ministry of Health Regulation No.7 Year 2019. ${ }^{6}$ We found that the $r$ humidity of the sampled inpatient rooms was fall into safe standard category, however, important note is the humidity of Dahlia room was $41 \%$ during visiting hours. The humidity was relatively low in the Dahlia room because it is located on the $3^{\text {rd }}$ floor of dr. Soebandi Regional Hospital Jember, so the duration and intensity of solar lighting could affect the level of humidity. ${ }^{13}$ Climate changes and ventilation systems can cause air flows changes depending on the conditions at that time. ${ }^{14}$ In this research, there was no significant results between humidity and the concentration of fungi. This insignificant results allegedly due to other factors that influence such as climate change that cause air flow frequently changes depending on the conditions at that time.

Measurement of light intensity in the inpatient room of dr. Soebandi Regional Hospital Jember in this study was conducted twice during visiting and non-visiting hours. The results of light intensity measurements showed a deficient number between 10-30 lux, whereas according to the Indonesia Ministry of Health Regulation No.7 Year 2019, the ideal light intensity of the inpatient room in the daytime is 250 lux. $^{6}$ This proves that the light intensity of the inpatient room of dr. Soebandi Regional Hospital Jember was well below the specified standards. There was no significant result between the intensity of light space with the concentration of fungi, both during visiting hours and non-visiting hours. This can be caused by bias factors that appear during visiting hours and nonvisiting hours, such as density of the room and climate that can increase several things. ${ }^{15}$

According to the Technical Guidelines for Hospital Environmental Health Requirements by the Republic of Indonesia Ministry of Health (2004), the recommended number of beds in the inpatient rooms is $2 \mathrm{~m}^{2} /$ bed for infant care and $4.5 \mathrm{~m}^{2} /$ bed for adult care. The good standard for room density that has no potential to spread diseases is one person/10 $\mathrm{m}^{2} .^{16}$ The inpatient room that is too crowded has some potential to distribute many diseases from patients to healthy people and vice versa. Many human activities, such as talking, coughing and walking, can produce any microorganism in the air. ${ }^{17}$ In this study, the results of the room density in the inpatient rooms of dr. Soebandi Regional Hospital Jember ranged from 1.95-2.95 person/10 $\mathrm{m}^{2}$ during visiting hours and 1.88-2.38 person/10 $\mathrm{m}^{2}$ during non-visiting hours. The room density was significantly associated with the concentration of fungi with coefficient of correlations 0.726 $(\mathrm{p}=0.041)$. The overcrowded room can affect health, and if a room has an over standard high-density level, it can allow disease transmission from one person to another. ${ }^{18}$ It can increase the risk factor of nosocomial infection, so the number of occupants in the room must be adjusted.

The results of macroscopic and microscopic identification of fungi with the help of lactophenol cotton blue staining obtained 10 different types of fungi which were in the air in the inpatient room of dr. Soebandi Regional Hospital, Jember. Research conducted by Nafilahsari (2018) only found three types of fungi in the inpatient rooms of dr. Soebandi Regional Hospital, namely Aspergillus spp, Penicillium spp, and Candida spp $p^{8}$ while the fungi identified in this latest study were Cladosporium cladosporioides, Aspergillus niger, Exophiala xenobiotica, Blastomyces dermatitidis, Penicillium spp, Neurospora crassa, Neoscytalidium dimidiatum, Alternaria spp, Trichosporon spp, and Chrysosporium spp. Cladosporium, Penicillium, and Aspergillus are the most commonly found fungi in the air. This occurs due to the number of spores that are large and light so they can dominate the air. ${ }^{19}$

These different types of fungus can be caused by differences in the fungi media used. Research conducted by Nafilahsari (2018) used Saboraud Dextrose Agar (SDA) media, whereas in this study we used Potato Dextrose Agar (PDA) media. The PDA media has a function to grow or identify fungi, mold and khami but it is not good for bacterial growth, whereas the SDA media is a medium that grows fungi which causes infections of the skin, hair or nails only. PDA media contains $20 \%$ potato extract and $2 \%$ glucose which is a source of carbohydrates and a nutrient enhancer for cultures on PDA media, whereas SDA media contains only $20 \%$ glucose and $5 \%$ mycological peptone for carbohydrate sources and nutrient enhancers making it less optimal for the development of various types of mushrooms. PDA media is not a medium for primary isolation of dermatophyte fungi either, so it is more easily contaminated and to accommodate various types of fungi in the air. ${ }^{20}$

The fungi found have different properties and pathogenicity. Cladosporium cladosporioides 
can grow well on PDA media. Cladosporium cladosporioides is macroscopically brown with a dark base. Cladosporium cladosporioides is thought to cause opportunistic infections in humans. The fungi can produce cladosporin and emodin, which are known as cytotoxic and mutagenic products. ${ }^{21}$

Aspergillus niger is generally black or dark brown. Humans are very easily exposed to these fungi given the spores are very small and lightweight so it is effortless to be scattered in the air. Aspergillus niger is thought to produce mycotoxin which triggers an allergic response to a carcinogenic response in the lungs, kidneys, and liver. Aspergillus niger can also cause infections in the ears and other organs, especially in people with inadequate immune systems. ${ }^{22}$ The mortality rate in aspergillosis cases ranges from around $40-90 \%$ depending on the location of the infection and the immunity status of the patient. ${ }^{23}$

Exophiala xenibiotica is a fungus that can grow easily in humid and hot environments. Exophiala xenibiotica is thought to be pathogenic in humans. This was proven by the discovery of cases of Exophiala xenibiotica fungal infections in patients with HIV in France. The pathophysiology of Exophiala xenibiotica fungal infection is not clear yet, but data indicates that mortality rates due to Exophiala xenibiotica infection are lower than infections due to other Exophiala species. ${ }^{24}$

Another fungi found in the inpatient room $\mathrm{dr}$. Soebandi Regional Hospital Jember is Blastomyces dermatitidis. Blastomyces dermatitidis is known as pathogenic fungi that can cause blastomycosis, an infection caused by a fungus that can be lifethreatening. Fungal infections can occur through an inhalation process. Humans can unconsciously inhale conidia from fungal scattered in the air. ${ }^{25}$ The surviving conidia will then reach the alveoli and can grow to the next phase considering that the optimal temperature for Blastomyces dermatitidis growth is normal body temperature. Blastomyces dermatitidis infection can spread to other parts of the body both through the blood and lymph nodes. ${ }^{26}$ Pneumonia caused by the fungi Blastomyces dermatitidis has a good prognosis if found without complications, but the mortality rate can increase up to $70 \%$ along with the severity of the disease. ${ }^{27}$

Fungal infections often occur in patients with inadequate immune systems. Airborne fungi have the potential to be pathogenic in humans, such as Penicillium spp which can cause pneumonia in patients with Systemic Lupus Erythematosus ${ }^{28}$ and Neoscytalidium dimidiatum which can cause pulmonary infections in patients with lymphoma. ${ }^{29}$ Other fungi has the potential to cause disease in humans due to the mycotoxin, such as Alternaria $s p p^{30}$ and Chrysosporium $s p p^{31}$, while 16 out of 50 species of Trichosporon spp are also pathogenic in humans. ${ }^{32}$ Almost all fungi found in the inpatient room of dr. Soebandi Regional Hospital is pathogenic, but one, Neurospora crassa is classified as non-pathogenic fungi. ${ }^{33}$

Based on the nature and pathogenicity of each type of fungi found in this study, it can be proven that the air quality of inpatient room of dr. Soebandi Regional Hospital was poor. The presence of fungal in the air can adversely affect everyone in the room, including patient, family, health care workers or even medical personnel on duty. The weakness of this study is that it does not collect detailed data regarding the number of colonies of each type of fungi. All types of fungus also do not grow in the same media. For example, Cladosporium cladosporioides is most commonly found in the inpatient rooms, while Chrysosporium sp. and Trichosporon sp. are most rarely found in inpatient rooms. Therefore further research regarding the quality of hospital air microbiology is needed.

\section{CONCLUSION}

We found the room temperature of inpatient rooms in dr. Soebandi Regional Hospital was between $29.6-32,2^{\circ} \mathrm{C}$, while the humidity was ranged from $4 \%$ to $59 \%$. The light intensity was around 10-30 lux, while the room density was $1.88-2.95$ people/ 10 $\mathrm{m}^{2}$. The concentration of fungal colonies obtained in this study was ranged from 1.63 to58.93 CFU/ $\mathrm{m}^{3}$ and consisted of ten types of fungi, namely Cladosporium cladosporioides, Aspergillus niger, Exophiala xenobiotica, Blastomyces dermatitidis, Penicillium spp, Neurospora crassa, Neoscytalidium dimidiatum, Alternaria spp, Trichosporon spp and Chrysosporium spp.

There is a correlation between room temperature and the concentration of fungi during visiting and non-visiting hours, also between room density and the concentration of fungi. The nature and pathogenicity of most fungi found in the inpatients room signify poor air quality of inpatient room at dr. Soebandi Regional Hospital. The presence of fungal in the air can adversely affect everyone including patients, family and health personnels. The management of hospitals should take measures to improve the air quality within inpatient rooms.

\section{ACKNOWLEDGMENTS}

The authors would like to acknowledge dr. Soebandi Regional Hospital stakeholders and the Dean of Faculty of Medicine, University of Jember, for their valuable contributions in facilitating this research. 


\section{AUTHOR CONTRIBUTION}

SMZ, AS, INS and DA designed the study, collected and analyzed the data, also wrote and edited the manuscript.

\section{CONFLICT OF INTEREST}

No conflicts of interest declared by the authors.

\section{REFERENCES}

1. World Health Organization. Household air pollution and health [Internet]. 2019 [cited 7 December 2019]. Available from: https://www.who.int/news-room/fact-sheets/detail/ household-air-pollution-and-health

2. Schulze F, Gao X, Virzonis D, Damiati S, Schneider M, Kodzius R. Air quality effects on human health and approaches for its assessment through microfluidic chips. Genes. 2017;8(10):244.

3. Azimi F, Naddafi K, Nabizadeh R, Hassanvand MS, Alimohammadi M, Afhami S, et al. Fungal air quality in hospital rooms: a case study in Tehran, Iran. J Environ Health Sci Engineer. 2013;11(1):30.

4. Ministry of Health of The Republic of Indonesia. Peraturan Menteri Kesehatan Republik Indonesia Nomor 27 Tahun 2017 tentang Pedoman Pencegahan dan Pengendalian Infeksi di Fasilitas Pelayanan Kesehatan [Indonesia Ministry of Health Regulation No. 27 Year 2017 on the Guidelines of Infections Prevention and Control at Health Care Facilities]. Jakarta; 2017.

5. Jayanti L, Manyullei S, Bujawati E. Kesehatan lingkungan udara ruang rawat inap Rumah Sakit Syekh Yusuf Kabupaten Gowa [Air environmental health of inpatient rooms at Syekh Yusuf Hospital, Gowa District]. Higiene. 2016; 2(1):33-40

6. Ministry of Health of The Republic of Indonesia. Peraturan Menteri Kesehatan Republik Indonesia Nomor 7 Tahun 2019 tentang Kesehatan Lingkungan Rumah Sakit [Indonesia Ministry of Health Regulation No. 7 Year 2019 on Environmental Health at Hospitals]. Jakarta; 2019.

7. Budhyowati MYN, Kindangen JI, Tungka AE. Analisis faktor-faktor yang mempengaruhi beban penyejukan pada bangunan yang menggunakan sistem pengkondisian udara [Analysis of factors which influence cooling load at buildings used air conditioning system]. Jurnal Arsitektur Daseng Unsrat Manado. 2016;5(1).

8. Ernawati D, Gunawan AT, Budiono Z. Faktor-faktor yang berhubungan dengan kondisi suhu dan kelembapan ruang keluarga di Dusun Kotayasa Desa Kotayasa Kecamatan Sumbang Kabupaten Banyumas Tahun 2016 [Factors associated with family room temperature and humidity in Kotayasa Village, Sumbang Sub-District, Banyumas District Year 2016]. Buletin Kelingmas. 2017;36(4):437-445.

9. Sari FN. Hubungan antara suhu dan kelembapan udara terhadap kualitas mikrobiologi udara di ruang rawat inap RSD dr. Soebandi Jember (Skripsi) [Association between temperature and humidity towards the air microbiology quality at the inpatient room of dr. Soebandi Hospital Jember (Undergraduate thesis)]. Universitas Jember; 2018.

10. Ministry of Health of The Republic of Indonesia. Keputusan Menteri Kesehatan Republik Indonesia Nomor 1335 Tahun 2002 tentang Standar Operasional Pengambilan dan Pengukuran Sampel Kualitas Udara Ruangan di Rumah Sakit [Indonesia Ministry of Health Decree No. 1335 Year 2002 on The Operational Standards on Collecting and Measuring Samples of Indoor Air Quality at Hospitals]. Jakarta; 2002.
11. Setyawardani A. Hubungan antara kepadatan ruangan, kelembapan, dan jumlah jamur pada ruang rawat inap RSD dr. Soebandi Jember (Skripsi) [The association between room density, humidity and number of fungi in the inpatient rooms at dr. Soebandi Hospital Jember (Undergraduate thesis)]. Universitas Jember; 2019.

12. Jung C-C, Wu P-C, Tseng C-H, Su H-J. Indoor air quality varies with ventilation types and working areas in hospitals. Building and Environment. 2015;85:190-195.

13. Hamdi S. Mengenal lama penyinaran matahari sebagai salah satu parameter klimatologi [Identifying lighting period as one of the climatology parameters]. Berita Dirgantara. 2014;15(1):7-16.

14. Ramdan IM. Perubahan iklim, dampak terhadap kesehatan masyarakat dan metode pengukurannya [Climate change, the impact on community health and the measurements]. 2017:11.

15. Kazemian N, Pakpour S, Milani AS, Klironomos J. Environmental factors influencing fungal growth on gypsum boards and their biodegradation: a university campus case study. Plos One. 2017;14(8): e0220556.

16. Ministry of Health of The Republic of Indonesia. KepMenKes RI No.1204/Menkes/SK/X/2004 tentang Persyaratan Kesehatan Lingkungan Rumah Sakit [Indonesia Ministry of Health Decree No. 1204/Menkes/SK/X/2004 on The Pre-requisites for Hospital Environmental Health]. Jakarta; 2004

17. Abdullah MT, Hakim BA. Lingkungan fisik dan angka kuman udara ruangan di Rumah Sakit Umum Haji Makassar, Sulawesi Selatan [Physical environment and number of air microorganisms at rooms of The Haji General Hospital, Makssar, South Sulawesi]. Kesmas:Nat Pub Hea Jour. 2011;5(5):206.

18. Mehta Y, Baig FK, Mehboob R. Nosocomial infections: epidemiology, prevention, control and surveillance. Asian Pasific Journal of Tropical Biomedicine. 2017;7(5):478-482.

19. Cabral JPS. Can we use indoor fungi as bioindicators of indoor air quality? Historical perspectives and open questions. Science of The Total Environment. 2010;408(20):4285-4295.

20. Gumral R, Aylin D, Mehmet MI. Comparison of the contamination rates of culture media used for isolation and identification of dermatophytes. Turkish Journal of Medical Sciences. 2015;45(3):587-592.

21. de Hoog GS, Chaturvedi V, Denning DW, Dyer PS, Frisvad JC, Geiser D, et al. Name changes in medically important fungi and their implications for clinical practice. J Clin Microbiol. 2015;53(4):1056-1062.

22. Gautam AK, Sharma S, Avasthi S, Bhadauria R. Diversity, pathogenicity and toxicology of a niger: an important spoilage fungi. Research J of Microbiology. 2011;6(3):270280.

23. Badiee P, Hashemizadeh Z. Opportunistic invasive fungal infetions: diagnosis \& clinical management. Indian Journal of Medical Research. 2014;139(2):195-204.

24. Morio F, Berre J-YL, Garcia-Hermoso D, Najafzadeh MJ, de Hoog S, Benard L, et al. Phaeohyphomycosis due to Exophiala xenobiotica as a cause of fungal arthritis in an HIV-infected patient. Med Mycol. 2012;50(5):513-517.

25. Nemeth NM, Campbell GD, Oesterle PT, Shirose L, McEwen B, Jardine CM. Red Fox as sentinel for Blastomyces dermatitidis, Ontario, Canada. Emerg Infect Dis. 2016;22(7):1275-1277.

26. Werner A, Norton F. Blastomycosis. MediMedia Animal Health. 2011;5.

27. Moore. NM, Proia LA. Severe acute respiratory distress syndrome in a liver transplant patient. Medical Mycology Case Reports. 2018;21:1-3. 
28. Mahomed S, Baijnath P, Mlisana K. Penicillium species: Is it a contaminant or pathogen? Delayed diagnosis in a case of pneumonia caused by penicillium chrysogenum in a systemic lupus erythematosus patient. International journal of tropical medicine and public health. 2016;6(1):4.

29. Dionne B, Neff L, Lee SA, Sutton DA, Wiederhold NP, Lindner $J$, et al. Pulmonary fungal infection caused by neoscytalidium dimidiatum. J Clin Microbiol. 2015;53(7):2381-2384.

30. Pinto VEF, Patriarca A. Alternaria species and their associated mycotoxins: Mycotoxigenic fungi [Internet]. New York, NY: Springer New York; 2017 [cited 2019 Nov 24]. p. 13-32.
31. Berikten D, Kivanc M. Fungal contaminations of some foods, their mycotoxin production and effects of antifungal agents on these fungi. In: Microbes in Applied Research [Internet]. Malaga, Spain: WORLD SCIENTIFIC; 2012 [cited 2019 Nov 24]. p. 268-72.

32. Montoya AM, González GM. Trichosporon spp.: an emerging fungal pathogen. Medicina Universitaria. 2014;16(62):37-43.

33. Gonçalves AP, Videira A. Programmed cell death in Neurospora crassa. New Journal of Science. 2014;2014:1-7.

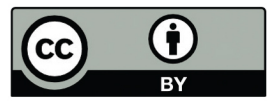

This work is licensed under a Creative Commons Attribution 